\title{
Biochemical Responses of Indian Mustard to Water Stress
}

\author{
Chitta Ranjan Sahoo $^{1 *}$, Manasi Dash ${ }^{2}$ and N. Acharya ${ }^{2}$ \\ ${ }^{1}$ Department of Plant Physiology, ${ }^{2}$ Department of Plant Breeding \& Genetics, College of \\ Agriculture, Orissa University of Agriculture \& Technology, Bhubaneswar, Odisha, India \\ *Corresponding author
}

\section{A B S T R A C T}

\section{Keywords}

Mustard, Water stress, Chlorophyll content, Nitrate Reductase activity, Proline content, Starch content, Free amino acid content

Article Info

Accepted:

15 January 2019

Available Online:

10 February 2019
Water stress was imposed on four varieties of Indian mustard viz., PusaBahar, Varuna, Pusa Jai Kisan and PusaAgraniby withholding irrigation at 3 different stages of crop growth i.e., vegetative, reproductive and pod-filling stage. The maximum impact of water stress on total chlorophyll content was observed at pod filling stage. The total chlorophyll content decreased a maximum in cv. PusaAgrani and minimum in Pua Jai Kisan. Proline accumulation increased in all the test verities and maximum accumulation was observed at reproductive stage. Cultivar Varuna registered the maximum proline accumulation. Total chlorophyll and proline content can be considered as the desirable traits for screening the cultivars for drought prone environments.

\section{Introduction}

Water stress during the crop ontogeny has been one of the main constraints for sustainable mustard productivity, especially in rainfed mustard growing tracts. Crop losses vary depending upon the genotype, physiology, intensity and duration of the stress. Improvement of the crop to water stress resistance through plant breeding is the best alternative. Cultivars with better ability to access soil water and improved water use efficiency could increase yield in an economic and environmentally sustainable way. Water deficit tolerance appears to be the result of co-ordination of morphological, physiological and biochemical alterations at the organ, cellular and molecular level leading to water stress resistance of crop plants (Reddy and Vanaja, 2006). Hence, consistency of performance despite the vagaries of climate, particularly rainfall and consequential, water availability, is an important selection criterion in breeding for drought, resistance (Lupton, 1980). Arnon (1980), therefore, advocated the use of widely adapted varieties in drought prone areas. Improving the yield potential of an already 
resistant material may be a more promising strategy, provided there is genetic variation within such a material. Transfer of an improved traits to already otherwise adapted varieties can proceed simple by accumulating beneficial alleles (Rajaram et al., 1996). In this context, Sinha and Khanna (1996) suggested to combine drought resistance with high yielding genotypes of crop species. According to them simultaneous selection in non-stress environment for yield and in drought conditions for stability may be done to achieve the desired goal of evolving drought resistant genotypes with high yielding potential. The present study aimed at assessing the water stress resistance characteristics of rainfed mustards popularly grown under agro-climatic zones of coastal Orissa and to suggest desirable putative traits on breeding for water stress resistance vis-àvis augmentation of mustard productivity.

\section{Materials and Methods}

The experimental material consisted of four mustard varieties viz., PusaBahar, Varuna, Pusa Jai Kisan and PusaAgrani. The experiment was conducted during rabi season at the Central Research Station, Orissa University of Agriculture and Technology, Bhubaneswar $\left(20^{0} 15^{\prime}\right.$ North; 85 $52^{\prime}$ ' East; $25.9 \mathrm{~m}$ AMSL) located in zone-III agroclimatic zone of Orissa (India). The soil of the experimental site is well drained sandy loam in texture with $\mathrm{pH}$ of 6.3 , organic carbon (0.36), total nitrogen (123 kg ha $\mathrm{kg}^{-1}$, available $\mathrm{P}_{2} \mathrm{O}_{5}\left(9.3 \mathrm{~kg} \mathrm{ha}^{-1}\right)$, and available $\mathrm{K}_{2} \mathrm{O}\left(118 \mathrm{~kg} \mathrm{ha}^{-1}\right)$. The crop was fertilized with 60,30 and $40 \mathrm{~kg} \mathrm{ha}^{-1}$ of $\mathrm{N}, \mathrm{P}_{2} \mathrm{O}_{5}$ andK $\mathrm{K}_{2} \mathrm{O}$ respectively. Other package of practices was followed as recommended for the place. Water stress was imposed by withholding irrigation at three stages of crop growth i.e., vegetative $\left(S_{1}\right)$, reproductive $\left(S_{2}\right)$ and podfilling $\left(\mathrm{S}_{3}\right)$ stage. The stress inductive cycle continued till incipient wilting of leaves. The field studies were conducted taking 16treatments combination (along with control, $\mathrm{S}_{0}$ ) laid out in factorial randomized block design (FRBD) with three replications. Total chlorophyll content in the leaves was determined by using the method stated by Arnon (1949). Nitrate reductase (NR) activity was determined as per the procedures of Hatam and Hume (1976). Proline accumulation was determined by estimating free proline content in the leaves according to the method of Bates et al., (1973) and Sadasivam and Manickam (1992) with slight modifications. The starch content and free amino acid content was determined according to the procedures of Sadasivam and Manickam (1992). Protein content was estimated according to the procedure of Lowry et al., (1951). The data obtained were analysed statistically in a factorial randomized block design (FRBD) and tested at 5 per cent level of significance (Cochran and Cox, 1977).

\section{Results and Discussion}

\section{Total chlorophyll content}

It was observed that total chlorophyll content significantly decreased in all the varieties and at all stages of growth in response to water stress when compared to control (Table 1 and $2)$. On exposure of plants to water stress at vegetative stage maximum reduction in chlorophyll content was recorded in Varuna (1.95 $\mathrm{mg} \mathrm{g}^{-1} \mathrm{FW}, 16.2 \%$ over control) followed by PusaBahar (1.75 $\mathrm{mg} \mathrm{g}^{-1} \mathrm{FW}$ ), PusaAgrani (1.69 $\mathrm{mg} \mathrm{g}^{-1} \mathrm{FW}$ ) and Pusa Jai Kisan (1.35 mg g $\mathrm{g}^{-1} \mathrm{FW}, 12.53 \%$ over control). At reproductive stage highest decrease was recorded for PusaAgrani with $3.21 \mathrm{mg} \mathrm{g}^{-1}$ FW (29.8 \% over control). However, stress at pod filling stage results a maximum decrease of $4.84 \mathrm{mg} \mathrm{g}^{-1} \mathrm{FW}$ (44.8 $\%$ over control) in PusaAgrani. Varuna recorded the least of decrease i.e. $4.30 \mathrm{mg} \mathrm{g}^{-1}$ 
FW (35.7\% over control) at pod filling stage. Among the varieties the highest mean values of total chlorophyll content across the growth stages was recorded for Varuna $\left(9.81 \mathrm{mg} \mathrm{g}^{-1}\right.$ FW) followed by PusaBahar (9.78 $\mathrm{mg} \mathrm{g}^{-1}$ FW) and Pusa Jai Kisan (8.49mg g $\left.\mathrm{g}^{-1} \mathrm{FW}\right)$ respectively. Among the growth stages the maximum impact of water stress was observed at pod filling stage (35.68-44.81\%) irrespective of varieties and the least was at vegetative stage.

Reduction in total chlorophyll content due to water stress was also reported by Sahu (2007). Decrease in chlorophyll content which is a lipoprotein, is ascribed to the net hydrolysis of proteins by decreased synthesis due to a decrease in available free energy that would accompany the decrease in respiration and photosynthesis (Levitt, 1980).

\section{Nitrate Reductase Activity (NRA)}

Nitrate reductase (NR) is the key enzyme of $\mathrm{N}$-metabolism which was investigated during the experiment for its response to water stress. Among the stages, moisture stress at reproductive stage had the most detrimental effect on NR activity irrespective of varieties, followed by vegetative and pod filling stage. The decrease in NRA ranged from $45.4 \%$ to $67.6 \%$ (Table 2 and Fig. 1).

At vegetative stage Varuna registered the maximum decrease of $18.68 \mu \mathrm{mol} \mathrm{NO}_{2}{ }^{-} \mathrm{g}^{-1}$ DW $\mathrm{h}^{-1}$ (47.8 \% over control). Stress at reproductive stage had the most detrimental effect on NR activity $(65.2-67.63 \%)$ with the highest decrease recorded for Varuna with $26.38 \mu \mathrm{mol}^{\mathrm{NO}_{2}^{-}} \mathrm{g}^{-1} \mathrm{DW} \mathrm{h}^{-1}(67.5 \%$ over that of control).

PusaAgrani recorded the least of decrease with $22.62 \mu \mathrm{mol} \mathrm{NO}_{2}^{-} \mathrm{g}^{-1} \mathrm{DW} \mathrm{h}^{-1}, 65.2 \%$ over control. However, when the plants were exposed to water stress at pod filling stage the maximum reduction of NRA of $22.76 \mu \mathrm{mol}$ $\mathrm{NO}_{2}^{-} \mathrm{g}^{-1} \mathrm{DW} \mathrm{h}{ }^{-1}$ (58.25\% over control) was recorded in cultivar Varuna.

Reductions in NRA due to water stress was also reported by Manjula et al., (2003) in castor genotypes, Das et al., (2000) in rice and Correia et al., (2005) in sunflower. Irrespective of species, the decrease in NRA was explained as the decreased rate of enzyme synthesis at low water potential (Morilla et al., 1973).

\section{Proline content}

The proline content of all the varieties irrespective of growth stages increased significantly compared to the respective controls when the plants were exposed to water stress (Table 2 and Fig. 2). The highest mean proline content was registered by Varuna (294.44 $\mu \mathrm{g} \mathrm{g}^{-1} \mathrm{FW}$ ) followed by PusaBahar (281.54 $\left.\mu \mathrm{g} \mathrm{g}{ }^{-1} \mathrm{FW}\right)$, PusaAgrani (280.46 $\mu \mathrm{g} \mathrm{g}^{-1} \mathrm{FW}$ ) and Pusa Jai Kisan (273.11 $\left.\mu \mathrm{g} \mathrm{g}^{-1} \mathrm{FW}\right)$. Most significant increase was recorded for stress at reproductive stage. Maximum increase in proline content was registered for Varuna at vegetative stage (163.66 $\mu \mathrm{g} \mathrm{g}^{-1} \mathrm{FW}, 113.6 \%$ over the control) as well as at reproductive stress $(316.08 \mu \mathrm{g}$ $\mathrm{g}^{-1} \mathrm{FW}$ ).

The increase was also significant when the plants were exposed to moisture stress at pod filling stage. Maximum increase of $121.83 \mu \mathrm{g}$ $\mathrm{g}^{-1}$ FW was registered by Varuna $(84.57 \%$ over control) followed by PusaAgrani (113.53 $\mu \mathrm{g} \mathrm{g} \mathrm{g}^{-1} \mathrm{FW}, 82.42 \%$ over control) and PusaBahar (113.03 $\mu \mathrm{g} \mathrm{g}^{-1} \mathrm{FW}, 81.08 \%$ over control). In general, proline content increased significantly under moisture stress. It has been suggested that proline accumulation confers adaptive mechanism to water stress (Aspinal and Paleg, 1981), acts as a nitrogen storage compound (Handa et al., 1986). 
Table.1 Effect of water stress on total chlorophyll content of leaves, soluble protein and free amino acids content of mustard varieties at Control (S0), Vegetative (S1), Reproductive (S2) and Pod filling (S3) stages

\begin{tabular}{|c|c|c|c|c|}
\hline Variety & $\begin{array}{c}\text { Stage of } \\
\text { crop growth }\end{array}$ & $\begin{array}{l}\text { Total Chlorophyll } \\
\quad\left(\mathrm{mg} \mathrm{g}^{-1} \text { FW) }\right.\end{array}$ & $\begin{array}{c}\text { Soluble protein } \\
\text { ( } \mu \mathrm{g} \text { g-1 DW) }\end{array}$ & $\begin{array}{l}\text { Free amino acids } \\
\quad\left(\mu \mathrm{g} \mathrm{g}^{-1} \mathrm{DW}\right)\end{array}$ \\
\hline \multirow{4}{*}{$\begin{array}{c}\text { PusaBahar } \\
\text { (V1) }\end{array}$} & S0 & 11.99 & 64.61 & 22.18 \\
\hline & $\mathrm{S} 1$ & 10.24 & 51.97 & 36.63 \\
\hline & $\mathrm{S} 2$ & 9.50 & 42.74 & 16.41 \\
\hline & S3 & 7.41 & 38.99 & 12.97 \\
\hline \multirow{4}{*}{$\begin{array}{l}\text { Varuna } \\
\text { (V2) }\end{array}$} & So & 12.05 & 65.21 & 22.08 \\
\hline & $\mathrm{S} 1$ & 10.10 & 53.51 & 36.56 \\
\hline & $\mathrm{S} 2$ & 9.34 & 42.65 & 18.15 \\
\hline & S3 & 7.75 & 38.67 & 12.55 \\
\hline \multirow{4}{*}{$\begin{array}{c}\text { Pusa Jai Kisan } \\
\text { (V3) }\end{array}$} & So & 10.77 & 64.64 & 22.80 \\
\hline & S1 & 9.42 & 53.12 & 35.71 \\
\hline & $\mathrm{S} 2$ & 7.68 & 42.37 & 16.01 \\
\hline & S3 & 6.10 & 38.88 & 12.31 \\
\hline \multirow{4}{*}{$\begin{array}{c}\text { PusaAgrani } \\
(\text { V4) }\end{array}$} & So & 10.80 & 63.26 & 21.83 \\
\hline & $\mathrm{S} 1$ & 9.11 & 52.43 & 35.23 \\
\hline & $\mathrm{S} 2$ & 7.59 & 41.86 & 17.04 \\
\hline & S3 & 5.96 & 38.57 & 11.89 \\
\hline \multicolumn{2}{|l|}{ Mean \pm SE } & 0.074 & 0.178 & 0.096 \\
\hline \multicolumn{2}{|l|}{$\mathrm{CD}(0.05)$} & 0.206 & 0.494 & 0.266 \\
\hline \multicolumn{2}{|l|}{ CV (\%) } & 5.636 & 2.741 & 3.319 \\
\hline
\end{tabular}

Table.2 Biochemical responses to water stress of mustard (Brassica juncea) varieties at different growth stages expressed as percent $(\%)$ reduction over control

\begin{tabular}{|c|c|c|c|c|}
\hline Treatments & Total chlorophyll & NRA & Proline content & Starch content \\
\hline Control & 0 & 0 & 0 & 0 \\
\hline $\mathbf{S}_{\mathbf{1}} \mathbf{V}_{\mathbf{1}}$ & -14.59 & -45.44 & 109.89 & $\mathbf{- 3 7 . 0 3}$ \\
\hline $\mathbf{S}_{\mathbf{1}} \mathbf{V}_{\mathbf{2}}$ & -16.18 & -47.81 & 113.61 & $\mathbf{- 3 1 . 9 0}$ \\
\hline $\mathbf{S}_{\mathbf{1}} \mathbf{V}_{\mathbf{3}}$ & -12.53 & -50.27 & 112.39 & $\mathbf{- 3 5 . 5 9}$ \\
\hline $\mathbf{S}_{\mathbf{1}} \mathbf{V}_{\mathbf{4}}$ & -15.65 & -45.57 & 116.96 & $\mathbf{- 3 4 . 5 3}$ \\
\hline $\mathbf{S}_{\mathbf{2}} \mathbf{V}_{\mathbf{1}}$ & -20.77 & -67.63 & 216.27 & $\mathbf{- 2 0 . 0 4}$ \\
\hline $\mathbf{S}_{\mathbf{2}} \mathbf{V}_{\mathbf{2}}$ & -22.49 & -67.52 & 219.42 & $\mathbf{- 1 5 . 7 4}$ \\
\hline $\mathbf{S}_{\mathbf{2}} \mathbf{V}_{\mathbf{3}}$ & -28.69 & -66.22 & 215.38 & $\mathbf{- 1 8 . 4 8}$ \\
\hline $\mathbf{S}_{\mathbf{2}} \mathbf{V}_{\mathbf{4}}$ & -29.72 & -65.20 & 215.08 & $\mathbf{- 1 7 . 7 4}$ \\
\hline $\mathbf{S}_{\mathbf{3}} \mathbf{V}_{\mathbf{1}}$ & -38.20 & -56.90 & 81.08 & $\mathbf{- 2 5 . 7 0}$ \\
\hline $\mathbf{S}_{\mathbf{3}} \mathbf{V}_{\mathbf{2}}$ & -35.68 & -58.25 & 84.57 & $\mathbf{- 2 1 . 4 8}$ \\
\hline $\mathbf{S}_{\mathbf{3}} \mathbf{V}_{\mathbf{3}}$ & -43.36 & -59.24 & 82.05 & $\mathbf{- 2 4 . 1 0}$ \\
\hline $\mathbf{S}_{\mathbf{3}} \mathbf{V}_{\mathbf{4}}$ & $\mathbf{- 4 4 . 8 1}$ & $\mathbf{- 5 6 . 6 1}$ & $\mathbf{8 2 . 4 2}$ & $\mathbf{- 2 4 . 1 2}$ \\
\hline
\end{tabular}


Fig 1. Effect of water stress on Nitrate Reductase Activity in Indian mustard

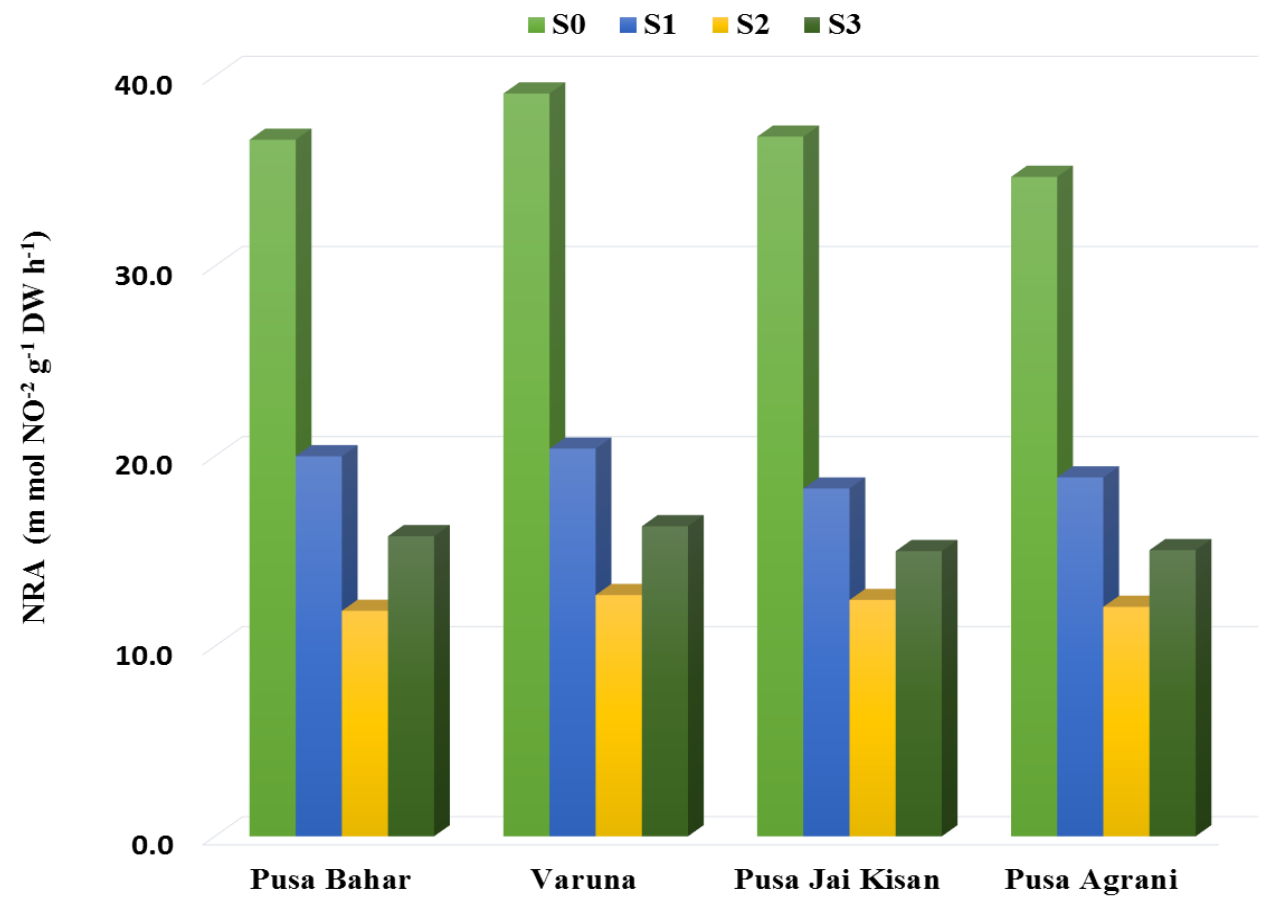

Fig 2. Effect of water stress on Proline content in Indian mustard

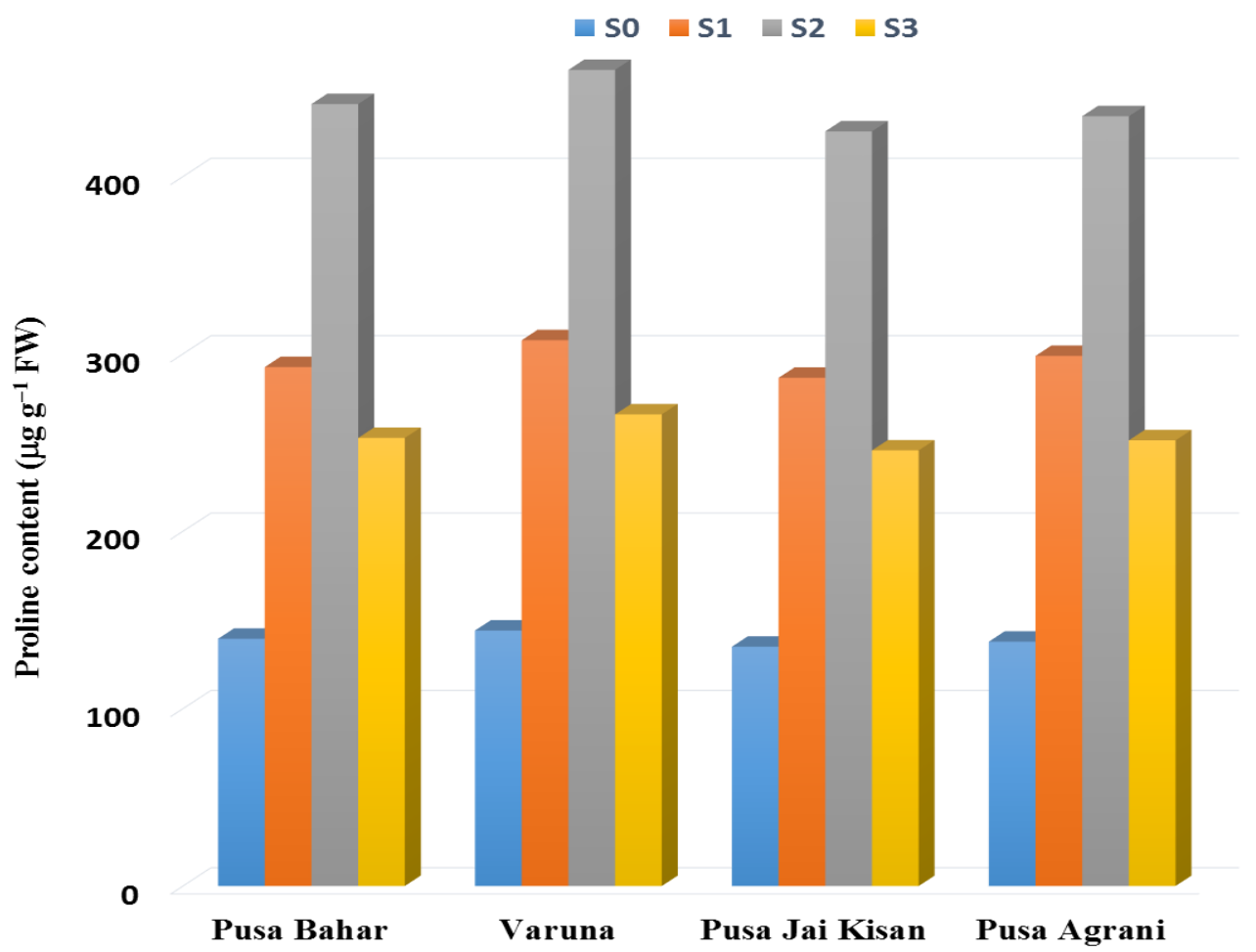


Fig 3. Effect of water stress on starch content in Indian mustard

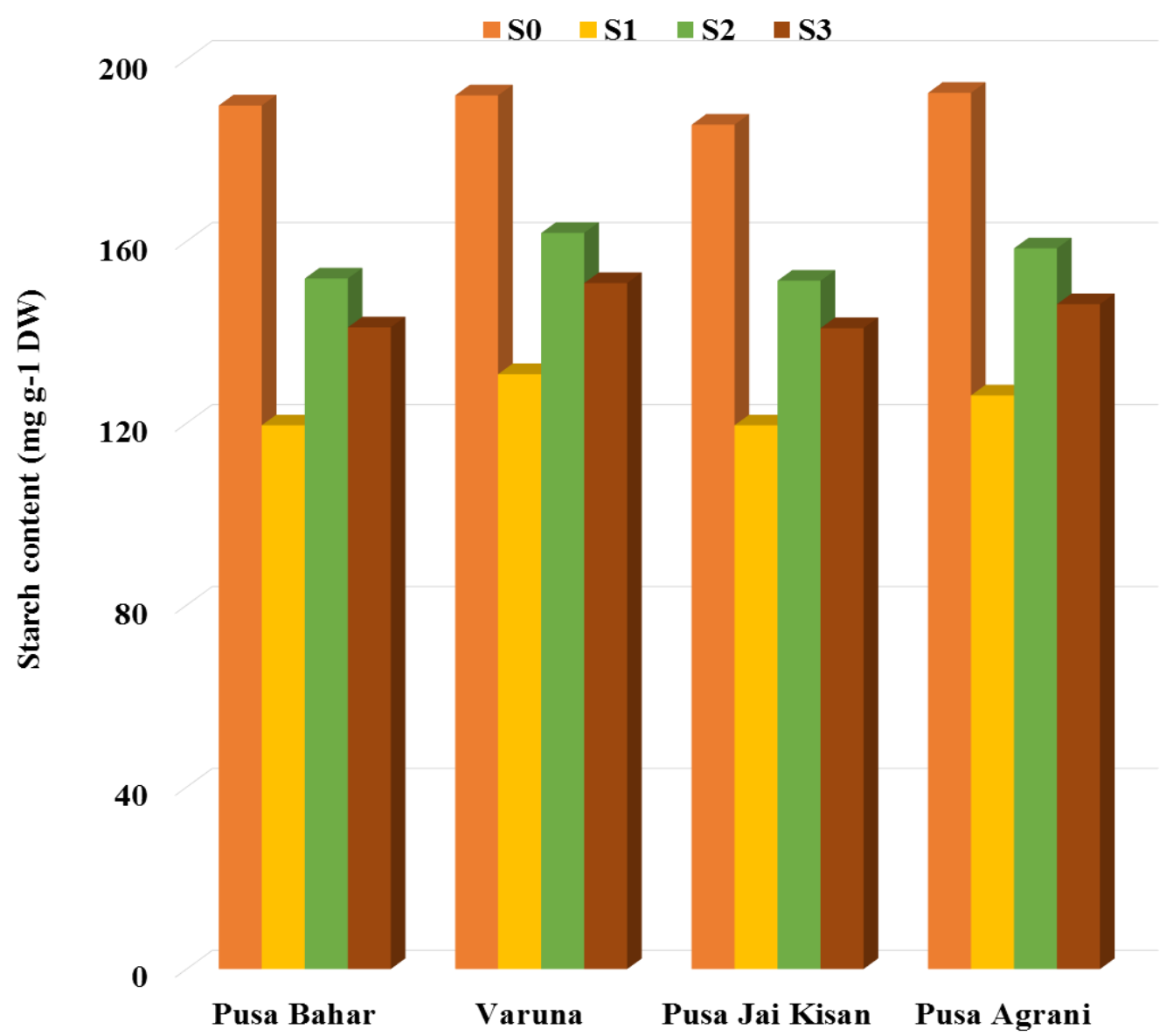

It also helps in stress tolerance either by rehydration of protoplasm or by providing energy for recovery of plants (Khidse et al., 1982). Tolerance to water stress with increased proline content was observed in castor (Manjula et al., 2003), groundnut (Koti et al., 1994) and sunflower (Garcia et al., 1992).

\section{Starch content}

The vegetative stage registered the highest decrease in starch content due to moisture stress (Table 2 and Fig. 3). Cultivar PusaBaharwas mostly affected in all the growth stages when exposed to water stress $(20-37 \%)$. The tolerant varieties Varuna and Agrani had higher starch content as compared to the other test varieties under stress condition. Decrease in starch content probably is due to high maintenance respiration or might be decreased rate of photosynthesis owing to stress-shock.

\section{Free amino acid}

It was seen that the free amino acid content increased significantly in all the varieties compared to their respective controls when water stress was applied at vegetative stage (Table 1). Among the varieties Varuna registered the highest increase of $14.48 \mu \mathrm{g} \mathrm{g}^{-1}$ DW (65.5\% over control). However, there was a significant reduction in free amino acid contents in all test varieties when water stress was applied at reproductive and pod filling stages. The decrease was the highest in Pusa Jai Kisan $\left(6.79 \mu \mathrm{g} \mathrm{g}^{-1}\right.$ DW, $29.8 \%$ over 
control) followed by PusaBahar $\left(5.77 \mu \mathrm{g} \mathrm{g}^{-1}\right.$ DW), PusaAgrani (4.79 $\left.\mu \mathrm{g} \mathrm{g} \mathrm{g}^{-1} \mathrm{DW}\right)$ and Varuna $\left(3.93 \mu \mathrm{g} \quad \mathrm{g}^{-1}\right.$ DW, $17.8 \%$ over control). Similarly when the plants were exposed to moisture stress at pod filling stage, a very significant decrease in free amino acid content was observed in Pusa Jai Kisan (10.49 $\mu \mathrm{g} \mathrm{g}^{-1} \mathrm{DW}, 46 \%$ over control) followed by PusaAgrani (9.94 $\mu \mathrm{g} \mathrm{g}^{-1} \mathrm{DW}, 45.5 \%$ over control). Across the growth stages the highest mean free amino acid content value was recorded for Varuna $\left(22.34 \mu \mathrm{g} \mathrm{g}^{-1} \mathrm{DW}\right)$ and the lowest mean fee amino acid content of $21.49 \mu \mathrm{g} \mathrm{g}^{-1} \mathrm{DW}$ value was rcorded for PusaAgrani. There was a mixed response to free amino acid content when mustard plants were exposed to water stress. The free amino acid content decreased significantly in all the growth stages except the vegetative stage (56.6 - 65.6\%) where it increased significantly. A maximum decrease was recorded for Pusa Jai Kisan $(29.8$ - 46\%) when exposed to water stress.

\section{Soluble protein}

Among the growth stages the pod filling stage recorded the highest decrease $(39-40.7 \%)$ in soluble protein content for all the varieties followed by reproductive and vegetative stage (Table 1). Cultivar PusaBahar recorded the highest decrease in soluble protein content with $12.64 \mu \mathrm{g} \mathrm{g}^{-1} \mathrm{DW}$ (19.56\% over control) followed by Varuna $\left(11.70 \mu \mathrm{g} \mathrm{g}^{-1} \mathrm{DW}\right)$ when stress was applied at vegetative stage. At reproductive stage a maximum decrease of $22.56 \mu \mathrm{g} \mathrm{g}^{-1} \mathrm{DW},(34.6 \%$ over control) was registered in case of Varuna followed by Pusa Jai Kisan (22.27 $\mu \mathrm{g} \mathrm{g}^{-1}$ DW). Similarly, for stress at pod filling stage highest decrease in soluble protein was observed in case of Varuna (26.54 $\mu \mathrm{g} \quad \mathrm{g}^{-1} \mathrm{DW}, \quad 40.7 \%$ over control). Among the varieties the maximum mean soluble protein of $50.01 \mu \mathrm{g} \mathrm{g}^{-1} \mathrm{DW}$ was registered by Varuna.
Seed protein content of the test cultivars decreased significantly due to water stress irrespective of growth stages. This is perhaps due to poor assimilatory and translocation process, which may have been hampered by impact of drought like conditions. Jha and Singh (1997) recorded similar results while working on rice varieties with varying degree of drought tolerance. This might have been due to the inherent ability of these plants to maintain their water balance in scarce periods there by its physio-biochemical processes being less affected due to moisture stress.

The total chlorophyll content, nitrate reductase activity (NRA), starch content and soluble protein content decreased significantly in all the varieties irrespective of growth stages in response to water stress. The proline accumulation increased in all the four mustard varieties irrespective of growth stages. There was a mixed response to free amino acid content when mustard plants were exposed to water stress.

\section{References}

Aggarwal, P.K., Singh A.K., Chaturvedi G.S. and Sinha S.K. (1986). Performance of wheat and triticale cultivars in a variable soil-water environment II. Evapotranspiration, water use efficiency, harvest index and grain yield. Field Crops Research 13: 303-315.

Arnon D.I. (1949). Copper enzyme in isolates chloroplasts, Polyphenol oxidase in Beta vulgaris. Plant Physiology 24: 1-5.

Arnon I. (1980). Breeding for higher yields. Coordinators Report In: Processing of the $15^{\text {th }}$ Colloquium of Int. Pol. Inst., Wageningen, The Netherlands, pp.:77-81.

Aspinall B. and Paleg L.G. (1981). Proline accumulation physiological aspects. In: B. Aspinall and L.G. Paleg. (Eds.). The physiology and biochemistry of Drought Resistance in Plants, Academic Press, Sydney. pp. 205-241.

Bates L.S., Waldren R.P. and Teare I.D. (1973). Rapid determination of free proline for water 
stress condition. Plant Soil, 39: 205-207.

Correia M.J., Fonseca F., Azedo-Silva J., Dias C., David M.M., Barrate I., Osoria M.L. and Osorio J. (2005). Effects of water deficit on the activity of nitrate reductase and content of sugars, nitrate and free amino acids in leaves, roots of sunflower and white lupin plants growing under two nutrient regimes. Physiologia Plantarum 124: 61-70.

Cochran W.S. and Gertrude M.C. (1977). Experimental Designs, 2nd edition, Wiley, New York.

Das K., Pradhan T., Ghosh S. and Mishra B.K. (2000). Evaluation of drought resistance characteristics of upland rice cultivars. Oryza 37: 4-6.

Garcia A.L., Galinda A.L. and Soldatini G.F. (1992). Biochemical effects of water and salt stress induced by sodium chloride and polyethylene glycol in sunflower seedlings. Agriculture Mediterranea 122: 322-327.

Handa S.A.K., Hasegawa P.M. and Bressan R.A. (1986). Proline accumulation and adaptation of cultured plant cells to water stress. Plant Physiology 80: 938-945.

Hatam M. and Hume D.J. (1976). Relation between nitrate reductase activity and nitrate accumulation in soybean. Canadian Journal of Plant Science 56:377-384.

Jha B.N. and Singh R.A. (1997). Physiological responses of rice varieties to different levels of moisture stress. Indian Journal of Plant Physiology 2(1): 81-84.

Khidse S.R., Bhale N.L. and Barikar S.T. (1982). Effects of water stress on proline accumulation in sorghum. Journal of Maharashtra Agriculture University 7: 195196.

Koti R.V., Chetti M.B., Manjunath and Ameragowda A. (1994). Effect of water stress at different growth stages on biophysical characters and yield in groundnut
(Arachis hypogaea L.) genotypes. Karnataka Journal of Agriculture Science 7: 158-162.

Levitt J. (1980). Response of the plants to environmental stresses vol. II. Water radiation, salt and other stresses. Academic Press, New York, London, Toronto.

Lowny O.H., Rosebrough N.J., Farr A.L. and Randall R.J. (1951). Protein measurement with the folin phenol reagent. Journal of Biology and Chemistry 193: 265-275.

Lupton F.G.H. (1980). Breeding for higher yields. In Physiological aspects of crop production. Werbiaufen, Bern. pp. 27-36.

Manjula K., Sarma P.S., Thatikunta R. and Rao T.N. (2003). Evaluation of castor (Ricinus communis L.) genotypes for moisture stress. Indian Journal of Plant Physiology 8 (3): 319-322.

Morilla, C.A., Boyer, J.S. and Hageman, R.H. (1973). Nitrate reductase activity and poly ribosomal content of corn [Zea mays L.] having low leaf water potential. Plant Physiology 51: 817-824.

Rajaram S., Barun H.J. and Van Ginkel M. (1996). CYMMYT's approach to breed for drought tolerance. Euphytica 92: 147-153.

Reddy K.J. and Vanaja M. (2006). Plant responses to drought stress. Journal of Plant Biology 33: $115-124$.

Sadasivam S. and Manickam A. (1992). Biochemical methods for agricultural sciences, Wiley Eastern Ltd.

Sahu A.K. (2007). Physiological and biochemical basis of drought tolerance in rice. Ph.D. thesis. Department of Plant Physiology, Orissa University of Agriculture and Technology, Bhubaneswar.

Sinha S.K. and Khanna Chopra R. (1996). Tolerance mechanism for crop improvement in drought and thermal environment. NARP Report, pp.1-63.

\section{How to cite this article:}

Chitta Ranjan Sahoo, Manasi Dash and Acharya, N. 2019. Biochemical Responses of Indian Mustard to Water Stress. Int.J.Curr.Microbiol.App.Sci. 8(02): 1711-1718. doi: https://doi.org/10.20546/ijcmas.2019.802.201 